\title{
Rigor development and meat quality of Murrah buffalo from different production
}

\section{systems}

\author{
Desenvolvimento do rigor e qualidade da carne de bubalinos Murrah de diferentes sistemas de \\ produção
}

Desarrollo del rigor y calidad de la carne de búfalos Murrah de diferentes sistemas de producción

\begin{abstract}
The purpose of this study was to evaluate the rigor mortis development and its effects on striploins quality of Murrah buffalos from meat (males) and dairy (females) productions. The rigor was monitored during carcass chilling (up to 22 $\mathrm{h}$ postmortem) and the meat physicochemical traits was accessed after $72 \mathrm{~h}$ postmortem. Glycolytic rate, measured by decreasing $\mathrm{pH}$ and glycogen content, was higher $(\mathrm{p}<0.05)$ in female than in male buffalo, leading to a different onset rigor time $(5-6 \mathrm{~h}$ and $9-10 \mathrm{~h}$, respectively). Male meat had $(\mathrm{p}<0.05)$ lower fat $(1.41 \mathrm{vs} 3.58 \%)$ and insoluble collagen (1.18 vs $1.58 \mathrm{mg} \mathrm{g-1)} \mathrm{contents,} \mathrm{but} \mathrm{higher} \mathrm{soluble} \mathrm{collagen} \mathrm{content} \mathrm{(5.16} \mathrm{vs} 20.38 \%)$, sarcomere length (1.65 vs 1.84 $\mu \mathrm{m})$, myofibrillar fragmentation (334 vs 295) and shear force (39.38 vs $25.92 \mathrm{~N}$ ) than females. These results suggest that dairy buffalo meat is more tender and can be used on the market as high-quality meat such as from buffalo raised to meat production.
\end{abstract}

Keywords: Sex; Tenderness; Glycogen; Sarcomere length; Myofibrillar fragmentation.

\section{Resumo}

O objetivo deste estudo foi avaliar o desenvolvimento de rigor mortis e seus efeitos na qualidade de contrafilés de búfalos Murrah provenientes de sistemas de produção de carne (machos) e de leite (fêmeas). O rigor foi monitorado durante o resfriamento (até $22 \mathrm{~h}$ post mortem) e as características físico-químicas da carne foram avaliadas após $72 \mathrm{~h}$ post mortem. A taxa glicolítica, medida pela redução do $\mathrm{pH}$ e do conteúdo de glicogênio, foi maior $(\mathrm{p}<0,05)$ em fêmeas do que em machos, levando a um tempo de início de rigor diferente (5-6 h e 9-10 h, respectivamente). A carne de búfalos machos teve ( $\mathrm{p}<0,05)$ menor teor de gordura $(1,41 \mathrm{vs} \mathrm{3,58 \% )} \mathrm{e} \mathrm{colágeno} \mathrm{insolúvel}(1,18 \mathrm{vs} 1,58 \mathrm{mg}$ g-1), mas maior conteúdo de colágeno solúvel (5,16 vs 20,38\%), comprimento do sarcômero (1,65 vs 1,84 $\mu$ m), índice de fragmentação miofibrilar (334 vs 295) e força de cisalhamento (39,38 vs 25,92 N) do que as fêmeas. Os resultados 
sugerem que a carne de fêmeas leiteiras é mais macia e pode ser classificada como de alta qualidade da mesma forma que búfalos para produção de carne.

Palavras-chave: Sexo; Maciez; Glicogênio; Comprimento do sarcômero; Fragmentação miofibrilar.

\section{Resumen}

El objetivo de este estudio fue evaluar el desarrollo del rigor mortis y sus efectos sobre la calidad de los filetes de búfalo Murrah de los sistemas de producción de carne (macho) y leche (hembra). La rigidez se controló durante el enfriamiento (hasta $22 \mathrm{~h}$ post mortem) y las características fisicoquímicas de la carne se evaluaron después de $72 \mathrm{~h}$ post mortem. La tasa de glucolítica, medida por la reducción del $\mathrm{pH}$ y el contenido de glucógeno, fue mayor $(\mathrm{p}<0,05)$ en las hembras que en los machos, lo que llevó a un tiempo de inicio diferente (5-6 hy 9-10 h, respectivamente). La carne de búfalo macho tenía ( $\mathrm{p}<0,05)$ menor contenido de grasa $(1,41$ vs $3,58 \%)$ y colágeno insoluble $(1,18$ vs 1,58 mg g-1), pero mayor contenido de colágeno soluble (5,16 vs 20,38\%), longitud del sarcómero (1,65 vs 1,84 $\mu \mathrm{m})$ ), índice de fragmentación miofibrilar (334 frente a 295) y resistencia al cizallamiento (39,38 frente a 25,92 N) que las mujeres. Los resultados sugieren que la carne de las hembras lecheras es más blanda y se puede clasificar como de alta calidad al igual que la de los búfalos para la producción de carne.

Palabras clave: Sexo; Suavidad; Glucógeno; Longitud del sarcómero; Fragmentación miofibrilar.

\section{Introduction}

Besides Brazil has the status of the highest concentration (1.39 million) of buffalos in the west (ABCB, 2020), the production, manufacturing process, and distribution of this segment has shown different characteristics that did not favor the valuation of the product by the consumer, who is unaware of its sensory and nutritional characteristics.

Due to its similarity to beef, buffalo meat is sold in Brazil in two different ways: as buffalo meat, usually of a highquality standard; and as beef, when they are attributed with an inferior quality or when they are not valued in the producing region. Murrah is the predominant buffalo breed in Brazil for having good adaption to the tropics and double aptitude for meat and dairy production, being usually reared in small and medium farms (ABCB, 2020). Such double aptitude intensifies the lack of carcass standardization in the country, especially in the southeast region. The main source of income from buffalo farming in such areas is the dairy activity in which the slaughter of young male is an alternative to increase the income of the producer (Luz, et al., 2017; Mello, et al., 2018). In addition to young buffaloes, dairy females at the end of production, presenting low milk production, or even with reproductive problems are also destined for slaughter to be sold as meat (Galeazzi, et al., 2010). The slaughter of unproductive and older buffaloes, especially dairy females, produces low-quality for consumer, especially low tenderness (Spanghero, et al., 2004; Kandeepan, et al., 2009; Li, et al., 2018).

Meat tenderness is also highly dependent on post-slaughter factors such as chilling processes, electrical stimulation, slaughter method, and aging (Toldra, 2017). In this sense, rigor mortis development is one of the main changes to take place in the postmortem muscle, influencing the meat quality characteristics such as texture and water retention capacity, and indirectly related to flavor and meat color (Ramos \& Gomide, 2017; Zhang, et al., 2019). Therefore, precise measurements of biochemical and mechanical characteristics that support the muscle transformation into meat are key factors for a better comprehension of buffalo meat quality, especially its tenderness. However, studies assessing the pH decline (Raj, et al., 2000; Neath, et al., 2007) and, or the evolution of the rigor mortis process (Soares, et al., 1995) in buffalo meat are scarce. As the lack of animal standardization is common in Brazilian commercial slaughterhouses, this work aimed to characterize the rigor mortis in Murrah buffalo carcasses with different quality standards (animals for meat and dairy production), evaluating its effects on the meat physicochemical traits related to tenderness.

\section{Methodology}

Ten Murrah buffaloes were selected in a commercial slaughterhouse in Boituva, São Paulo, Brazil. The animals were split into two groups: five males (24-30-month-old and average live weight of $456 \pm 13 \mathrm{~kg}$ ) from meat production that were classified by the slaughterhouse for the premium market; and five females (36-42-month-old and average live weight of $447 \pm$ 
$34 \mathrm{~kg}$ ) from dairy production farms that were classified for the common market. Despite being animals from different production systems, all buffaloes came from herds in the Vale do Ribeira region (São Paulo, Brazil) and were raised in a pasture feeding system (predominant native forage: Brachiaria sp.). The carcasses were not electrically stimulated and were moved to a chilling room $30 \mathrm{~min}$ after slaughter. This time was set to $0 \mathrm{~h}$ postmortem. Chilling system was conducted in two cooling chambers, with the half-carcasses kept in the first chamber $\left(10-15^{\circ} \mathrm{C}\right)$ until $12 \mathrm{~h}$ postmortem and then transferred to a second chamber $\left(0-2{ }^{\circ} \mathrm{C}\right)$, where they remained until boning and packaging $(48 \mathrm{~h}$ postmortem).

Early postmortem changes were monitored throughout striploin (M. Longissimus thoracis; LT) cooling, between the 12th and 13th ribs of the right half-carcasses. The LT muscle $\mathrm{pH}$ and temperature were evaluated at $0,1,5,8,12$, and $22 \mathrm{~h}$ postmortem using a portable pH meter (HI 99163; Hanna Instruments, Woonsocket, RI, USA). Freshly cut samples $(\sim 4 \mathrm{~g})$ were collected at each postmortem time and immediately deproteinized in $80 \mathrm{~mL}$ of $0.6 \mathrm{M}$ perchloric acid, being homogenized (Turratec TE102: TECNAL Equipamentos Científicos, Piracicaba, SP, Brazil) at $15.000 \mathrm{rpm}$ for $30 \mathrm{~s}$. The homogenate was filtered and kept frozen at $-20^{\circ} \mathrm{C}$ until glycogen and R-value analysis.

The glycogen content was enzymatically hydrolyzed into free glucose with amyloglucosidase (Sigma A9913; SigmaAldrich Brasil Ltda, São Paulo, SP, Brazil), mixing $100 \mu \mathrm{L}$ aliquot of the acid extract with $10 \mu \mathrm{L}$ of $5.4 \mathrm{M} \mathrm{KOH}$ and $1.0 \mathrm{~mL}$ of enzyme suspension $(0.3: 10 \mathrm{v} / \mathrm{v}$, in $0.2 \mathrm{M}$ acetate buffer, $\mathrm{pH} 4.8)$. After incubation of $60{ }^{\circ} \mathrm{C}$ for $15 \mathrm{~min}$, the free glucose was colorimetric determined by the redox reaction between the 3,5- dinitrosalicyclic acid (DNS) and the reducing sugars as proposed by Miller (1959). Glycogen concentration was determined using an analytical curve of standard glucose solutions and was expressed in millimoles of glucose equivalent (GEq) per kilogram (mmol GEq kg-1). Rigor onset was estimated analyzing the ratio of inosine and adenosine (R-value) as proposed by Honikel \& Fisher (1977), with modification suggested by Ramos \& Gomide (2017). An aliquot of $100 \mu \mathrm{L}$ of thawed perchloric acid extract was homogenized with $4.9 \mathrm{~mL}$ of $0.1 \mathrm{M}$ phosphate buffer (pH 7.0) and its absorbance was determined at $250 \mathrm{~nm}(\mathrm{~A} 250 \mathrm{~nm})$ and $260 \mathrm{~nm}$ (A260nm) with a UV spectrophotometer (Genesys 10; Thermo Fisher Scientific Inc., Waltham, MA, USA). The R-value was calculated as an A250nm /A260nm ratio.

At $48 \mathrm{~h}$ postmortem, boneless striploin from the left half-carcasses were completely excised, trimmed, identified, vacuum-packed, and transported to the laboratory, being kept refrigerated $\left(4 \pm 1{ }^{\circ} \mathrm{C}\right)$ overnight until the technological analyses (at $72 \mathrm{~h}$ postmortem). The $\mathrm{pH}$ was measured and approximately $200 \mathrm{~g}$ of LT muscle was grounded to determine the proximate composition (protein, fat, moisture, and ash) by near-infrared (NIR) analysis (FoodScanTM; FOSS, Hillerod, Denmark) and collagen content. The soluble and insoluble collagen fractions were separated (after heating at $77{ }^{\circ} \mathrm{C}$ for $70 \mathrm{~min}$ ) and the collagen content (mg g-1) was quantified by determining the amount of the hydroxyproline amino acid as described by Ramos and Gomide (2017). LT grounded samples were homogenized (1:5 ratio; w/v) in extraction solution ( $250 \mathrm{mM}$ sucrose and 20 $\mathrm{mM} \mathrm{KCl}$ at $4{ }^{\circ} \mathrm{C}$ ) and the myofibrillar fragmentation degree was estimated by the fragmentation index (FI) method described by Aroeira et al. (2020). A drop of the FI homogenate was also analyzed at 400x zoom, using a phase-contrast microscope (BA210, Motic, Hong Kong) with image capture software (Motic Images Plus 2.0), to determine the sarcomere average lengths (Ramos \& Gomide, 2017). At least 10 different fibers from 10 different aliquots for each sample was used to determine the sarcomere length.

Finally, a $2.54 \mathrm{~cm}$ thick freshly cut LT was weighted and grilled on a pre-heated $\left(180-200^{\circ} \mathrm{C}\right)$ grill $(\mathrm{SCGE}$; Croydon, Duque de Caxias, RJ, Brazil) up to an internal temperature of $71^{\circ} \mathrm{C}$ (Chugod- Smart Wireless BBQ Thermometer). The cooked steak was cooled at room temperature for $2 \mathrm{~h}$, dried with a paper towel, and weighted once again to determine the cooking loss (\%). Then, six sub-samples $(1.0 \times 1.0 \mathrm{~cm}$ square section) were cut parallel to the muscle fiber direction and sheared transversely (across the predominant muscle fiber orientation) at $200 \mathrm{~mm}$ min-1 (Silva et al., 2015) using a Warner Bratzler blade coupled to a TA.XT plus texturometer (Stable Micro Systems Ltd., Godalming, Surrey, United Kingdom). The maximum strength $(\mathrm{N})$ average value of each steak was used for statistical analysis. 
Concerning the early postmortem changes analyses, the experiment was organized in a completely randomized design (CRD) with a factorial scheme 2 (production system/sex) x 6 (postmortem times) and five repetitions (animals). The main effects and their interactions were determined by analysis of variance (ANOVA) at a 5\% significance level. A regression analysis was performed to estimate rigor onset from the R-value data. The data from the physicochemical analyses were also tested by ANOVA ( $\mathrm{p}<0,05)$, in a CRD with two groups (production system/sex) and five repetitions (animals). Statistical analyses were performed using Statistica software (StatSoft Inc., Tulsa, USA), version 8.0.

\section{Results and Discussion}

There was a considerable drop in temperature of the LT muscles during the first eight hours of chilling (from $36.47 \pm$ $1.72{ }^{\circ} \mathrm{C}$ to $22.01 \pm 0.85^{\circ} \mathrm{C}$ ) and then, with the relocation of the half-carcasses to the second cooling chamber, a temperature decreased to $10.19 \pm 1.34^{\circ} \mathrm{C}$ at $22 \mathrm{~h}$ postmortem (Figure 1a). This pattern of temperature decline was consistent with the "delayed chilling" regime described by Savell et al. (2005), in which the intact carcasses are held at temperatures between 14 and $19{ }^{\circ} \mathrm{C}$ for some period before chilled in a cold chamber to reduce or prevent the negative effects of cold shortening. Cold shortening is a myofibrillar shortening that happens when the pre-rigor muscle is kept at temperatures below $15^{\circ} \mathrm{C}$. This leads to a high calcium level in the sarcoplasm with ATP presence (when $\mathrm{pH}$ is higher than 6.0 in meat with normal final $\mathrm{pH}$ ), promoting the actin-myosin cross-bridges formation and resulting in the meat of greater toughness (Zhang, et al., 2019).

The $\mathrm{pH}$ values were affected $(\mathrm{p}<0.05)$ by the sex (production system) and time postmortem (Figure 1b). Higher ( $\mathrm{p}<$ $0.05)$ initial $\mathrm{pH}$ values (30 min postmortem) were observed in male buffalo muscle $(6.76 \pm 0.17)$ in relation to females $(6.41 \pm$ 0.19). This may be associated with greater muscle adaptation in the absence situation of oxygen supply. Muscles with higher $\mathrm{pH}$ during the first postmortem hours have higher proportions of oxidative fibers and, therefore, a higher amount of stored oxygen. A longer period is then required to resort to glycolytic metabolism and that causes a more pronounced initial $\mathrm{pH}$ drop (Toldra, 2017). Higher red fibers proportion may indicate stronger muscle activity during raising, which is expected from young males raised under extensive conditions when compared to females raised for dairy purposes.

Overall, the $\mathrm{pH}$ drop rate was consistent with the temperature decline, leading to a high glycolytic rate during the first 12 hours and reaching values that remained practically constant up to $22 \mathrm{~h}$ postmortem. The final $\mathrm{pH}$ values (average $5.54 \pm$ 0.08) did not differ significantly ( $\mathrm{p}$ < 0.05). Pearce et al. (2011) reported that a period of five hours is necessary for the cattle muscle $\mathrm{pH}$ to drop from 6.8 to 6.4 , and that only after $24 \mathrm{~h}$ postmortem it is stabilized at up to 5.5 . Therefore, it is presumably that the high postmortem muscle temperature in the delay chilling regime increased the action of glycolytic enzymes, which contribute to the increase in the $\mathrm{pH}$ drop rate. Raj et al. (2000) also observed a higher $\mathrm{pH}$ drop during the first six hours in excised buffaloes' muscles (Biceps femoris, Semimembranosus, and Semitendinosus) subjected to a delayed chilling process ( $26^{\circ} \mathrm{C} / 6 \mathrm{~h}$ followed by $2-3^{\circ} \mathrm{C} / 18 \mathrm{~h}$ ) when compared to the traditional method $\left(2-3^{\circ} \mathrm{C} / 24 \mathrm{~h}\right)$.

Even though the glycogen postmortem decay was similar (Figure 1c), higher average levels of glycogen were observed $(\mathrm{p}<0.05)$ in males $(90.13 \pm 13.87 \mathrm{mmol} \mathrm{GEq} \mathrm{kg}-1)$ than in females $(66.98 \pm 12.05 \mathrm{mmol}$ GEq kg- 1$)$. However, the chilling system used in this study may have promoted a quick glycogen depletion and consequent muscle acidification. At the beginning of the slaughter process, the depletion of glycogen content in females $(74.41 \pm 13.65$ mmol GEq kg-1) was higher ( $p$ $<0.05)$ than that of males $(105.57 \pm 11.34 \mathrm{mmol} \mathrm{GEq} \mathrm{kg-1)}$, which corroborates the higher glycolytic rate in dairy buffaloes when analyzed by the initial $\mathrm{pH}$ values. After slaughter, the muscle tries to keep ATP levels and activates catabolic routes to use glycogen stores as an energy source. The typical muscle glycogen concentration of well-fed and resting bovines ranges from 80 to $140 \mathrm{mmol} \mathrm{GEq} \mathrm{kg-1} \mathrm{(Immonen} \mathrm{\&} \mathrm{Puolanne,} \mathrm{2000),} \mathrm{but} \mathrm{the} \mathrm{pre-slaughter} \mathrm{management} \mathrm{associated} \mathrm{with} \mathrm{the} \mathrm{animal's}$ stress susceptibility may change these initial muscle glycogen concentrations. According to Toldra (2017), muscle conversion in bovines provides meat with a normal final $\mathrm{pH}$ when it contains from 10 to $20 \mathrm{mg}$ g- 1 of glycogen (approximately 55 and 
$110 \mathrm{mmol}$ GEq kg-1, respectively) at the slaughter moment. These authors also state that glycogen contents lower than $10 \mathrm{mg}$ g-1 would result in an elevated final $\mathrm{pH}$ and that the lower the initial glycogen store is, the higher the final $\mathrm{pH}$ values will be. Thus, the observed values found in muscles of both groups in the present study are within the normal range, which explains the lack of difference between $\mathrm{pH}$ values at $22 \mathrm{~h}$ postmortem.

Figure 1. Changes in temperature (a), $\mathrm{pH}$ values (b), glycogen content (c) and (d) R-values (inosine/adenosine ratio) of L. thoracis muscles of Murrah $(\diamond)$ female (from dairy production) and $(\diamond)$ male (from meat production) buffaloes during delayed chilling. GEq = glucose equivalent. $\mathrm{R}$-values regressions: Rfemale $=0.8243+0.0443 \times$ Hour, $\mathrm{P}<0.01, \mathrm{R} 2=0.73$; and Rmale $=0.7979+0.0289 \times$ Hour, $\mathrm{P}<0.01, \mathrm{R} 2=0.77$.
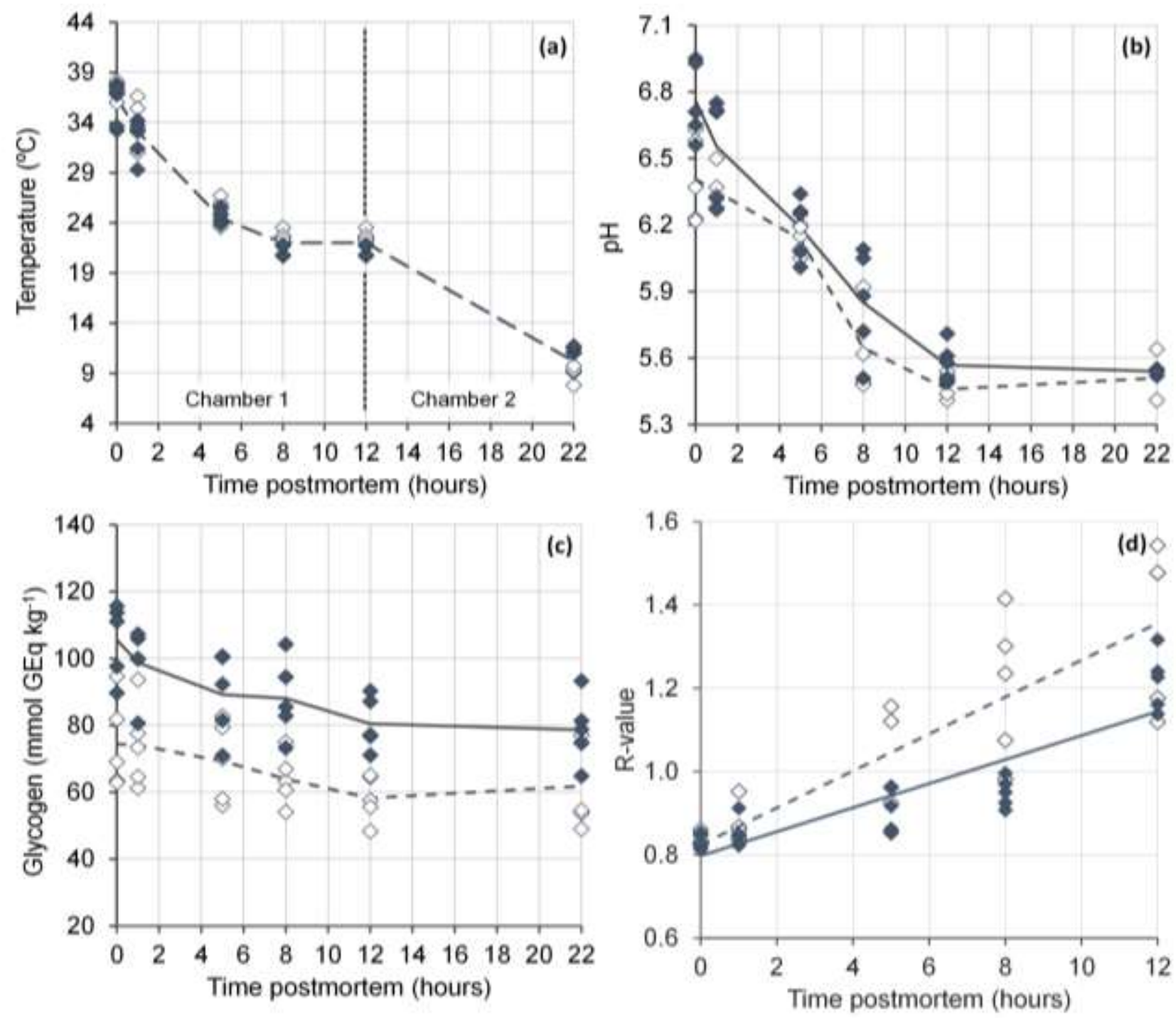

Source: Authors.

Rigor onset was determined by the R-values evolution in LT muscles. The R-value is a muscle cell's inosine and adenosine proportion measurement, and its postmortem increase is an ATP depletion indication which occurs during rigor mortis development (Ramos \& Gomide, 2017). R-values between 1.05 and 1.10 correspond to an ATP concentration of 1.0 $\mu \mathrm{mol}$ g-1 and, therefore, they are related to the rigor onset (Honikel \& Fisher, 1977). Since refrigeration was conducted in two stages and the glycolytic process happened almost entirely during the first stage (Figure 1b), the regression was performed with 
R-values data up to $12 \mathrm{~h}$ postmortem (Figure 1d). This was a reasonable assumption, since as the ATP content approached zero, the R-value would tend to infinite because the inosine content (numerator) increased as the adenosine content (denominator) decreased during the postmortem time. Data regression analyses indicated that the R-value rate was significantly higher for female than male, which resulted from the more intense adenine nucleotides catabolism associated with postmortem metabolism. Consequently, rigor onset happened between 8.7 and $10.5 \mathrm{~h}$ postmortem in males' muscle and between 5.1 and $6.2 \mathrm{~h}$ postmortem in females' muscle. These rigor times are consistent with the $\mathrm{pH}$ values evolution observed in the animals' meat (Figure 1b), in which values close to 5.9 were reached after $6 \mathrm{~h}$ for females and $8 \mathrm{~h}$ for males. According to Ramos and Gomide (2017), $\mathrm{pH}$ values close to 5.9 indicate rigor onset. Using these criteria (R-values 1.1 and $\mathrm{pH}$ 5.9), Soares et al. (1995) detected that the electrical stimulation process significantly reduced the time required for rigor onset in buffaloes' muscles ( $2 \mathrm{~h}$ ) compared to the unstimulated $(14 \mathrm{~h})$.

It is known that strategies to accelerate postmortem glycolysis rate to avoid phenomena such as cold shortening are crucial for the ideal meat quality. In this study, the cold shortening phenomena was effectively avoided since LT muscles reached temperatures below $15^{\circ} \mathrm{C}$ long after $(16 \mathrm{~h})$ the rigor onset $(6-10 \mathrm{~h})$. In this sense, half carcasses aging time in chamber one (at $15^{\circ} \mathrm{C}$ ) can be reduced to 6 to $8 \mathrm{~h}$, accelerating or processing chilling without cold shortening-related problems. The effects of delay chilling on meat physicochemical traits of male and female buffaloes $72 \mathrm{~h}$ postmortem are shown in Table 1. Final $\mathrm{pH}$ values did not differ $(\mathrm{p}>0.05)$ between sex and are within the range $(\mathrm{pH} 5.5$ - 5.8) considered as normal for beef (Toldra, 2017) and the reported (pH 5.4 - 5.7) range for buffalo meat (Kandeepan, et al., 2009; Luz, et al., 2017; Mello, et al., 2018). Male buffaloes' meat presented $(\mathrm{p}<0.05)$ higher moisture and ash contents and lower fat content in relation to the females, whereas the protein content did not differ $(p>0.05)$ between sex. This is possible due to two factors: fat is the later tissue to be deposited in the carcass and, therefore, older animals (in this case females with $\sim 12$ months older) tend to be fatter; and, associated with this, females reach maturity earlier (Toldra, 2017). Thus, the lower moisture content in female's meat is due to the fat's diluting effect in the proximate composition. Kandeepan et al. (2009) also observed a higher fat content in females than male buffalo meat.

The females' meat also presented $(\mathrm{p}<0.05)$ higher total collagen contents with a higher amount of the insoluble fraction and a lower amount of the soluble fraction than males' meat. These differences are probably due to the differences in the animals' age. As animals get older, collagen cross-bridges are stabilized and the fibrils' average diameter increase. Thus, molecules become more resistant to tension forces and its solubility is decreased in the face of heat (Toldra, 2017; Ramos \& Gomide, 2017): this contributes to the resistance of older animal's meat. The older age of females may also be responsible for the observed $(p<0.05)$ shorter sarcomeres than males. Sarcomere lengths found in this experiment $(1.64$ to $1.84 \mu \mathrm{m})$ are quite similar to those reported by Kandeepan et al. (2009), who also observed greater shortening in old female's buffalo meat (1.56 $\mu \mathrm{m})$ than in young males $(1.83 \mu \mathrm{m})$. These authors also observed a higher content of total collagen and lower solubility of such collagen in old female buffaloes' meat than in young male's meat. 
Table 1. Mean values ( \pm standard deviation) of the technological characteristics of L. thoracis muscles of Murrah female (from dairy production) and male (from meat production) buffaloes.

\begin{tabular}{lccc}
\hline Characteristics & Female & Male & $\boldsymbol{p}_{\text {-value }}$ \\
\hline $\mathrm{pH}$ & $5.59 \pm 0.06$ & $5.53 \pm 0.02$ & 0.089 \\
Proximate composition (\%) & & & \\
Moisture & $72.65 \pm 0.93$ & $74.42 \pm 0.25$ & $\mathbf{0 . 0 1 1}$ \\
Protein & $22.13 \pm 1.14$ & $20.86 \pm 1.00$ & 0.226 \\
Fat & $3.58 \pm 1.59$ & $1.45 \pm 0.58$ & $\mathbf{0 . 0 4 5}$ \\
Ash & $1.65 \pm 0.80$ & $3.47 \pm 0.72$ & $\mathbf{0 . 0 1 9}$ \\
Collagen $\left(\mathrm{mg} \mathrm{g}^{-1}\right)$ & & & \\
Total & $1.58 \pm 0.16$ & $1.18 \pm 0.3$ & $\mathbf{0 . 0 4 7}$ \\
Insoluble & $1.49 \pm 0.14$ & $0.96 \pm 0.29$ & $\mathbf{0 . 0 1 1}$ \\
Soluble & $0.08 \pm 0.04$ & $0.22 \pm 0.03$ & $\mathbf{0 . 0 0 1}$ \\
Soluble collagen $(\%)$ & $5.16 \pm 2.21$ & $20.38 \pm 4.78$ & $\mathbf{0 . 0 0 1}$ \\
Sarcomere length $(\mu \mathrm{m})$ & $1.64 \pm 0.21$ & $1.84 \pm 0.08$ & $<\mathbf{0 . 0 0 1}$ \\
Cooking loss $(\%)$ & $19.93 \pm 4.06$ & $22.04 \pm 4.39$ & 0.482 \\
Fragmentation index, IF & $295 \pm 37$ & $334 \pm 41$ & $\mathbf{0 . 0 4 8}$ \\
Shear force, WBsSF $(\mathrm{N})$ & $17.63 \pm 2.55$ & $26.77 \pm 6.04$ & $\mathbf{0 . 0 4 2}$ \\
\hline
\end{tabular}

WBsSF $=$ Warned-Bratzler square Shear Force.

${ }^{1}$ Significant probabilities $(\mathrm{p}<0.05)$ have been highlighted in bold.

Source: Authors.

Therefore, the lower insoluble collagen content, higher soluble collagen proportion, and higher sarcomere lengths of males' muscles are favorable for a greater meat tenderness. However, the fragmentation index values (FI) were lower ( $p<$ 0.05 ) in the females' meat, indicating higher proteolysis during postmortem than in male's meat. Likewise, the shear force (WBsSF) of the females' meat was lower $(\mathrm{p}<0.05)$ than that of the males' meat. Meat tenderness is a result of different factors, such as quantity and solubility of the conjunctive tissue, sarcomere shortening during rigor development, and myofibril proteins postmortem proteolysis (Dransfield, 1994). However, Culler et al. (1978) reported that myofibrillar fragmentation is responsible for over $50 \%$ of the striploin's tenderness variation while collagen solubility represented only about $10 \%$ of this variation. Moreover, the sarcomere length effect over meat tenderness depends on the cause of the muscle shortening, affecting meat tenderness when proteolysis is limited (Hwang, et al., 2004). Therefore, it is believed that the higher impact in tenderness in the present study was due to the more intense proteolysis that happened during the first $72 \mathrm{~h}$ postmortem.

Chilling affects meat tenderness mainly through its effects on the pH-temperature drop, physical disruption, and proteolysis. As rigor development rate increases, the enzymes are activated earlier at the normally higher prevailing temperature (Zhang, et al., 2019). Meat tenderization starts when $\mu$-calpain (or calpain I) is activated, normally at pH 6.2-6.3 in beef, and rapidly increases as higher levels of calpain are activated. This process lasts until running out of enzymes (Dransfield, 1994; Hwang, et al., 2004). In this sense, the differences in IF and WBsSF values observed between groups in this experiment could be related to a higher initial $\mu$-calpain activity in the females' muscles, which reached a pH close to 6.2 earlier than the males' muscles (Figure 1b).

Despite the WBsSF differences between sex (production systems), in general, both meats can be classified as "very 
tender". Considering the Warner-Bratzler shear force (WBSF) values determined as beef tenderness thresholds by Destefanis et al. (2008) and using the overall equation suggested by Silva et al. (2015) to convert WBSF to WBsSF values, meat with WBsSF lower than $53 \mathrm{~N}$ should be considered "tender" and with WBsSF higher than $69 \mathrm{~N}$ should be considered "tough". WBsSF values observed in this experiment are below those reported in the literature (WBSF 41-48 N or WBsSF 51-62 N) for not aged meats of water buffaloes with 24-36 months older (Spanghero, et al., 2004; Ekiz, et al., 2018; Li, et al., 2018; Mello, et al., 2018). This greater tenderness $72 \mathrm{~h}$ postmortem can be attributed to the chilling process adopted and the consequent greater proteolysis.

\section{Conclusion}

Female (from dairy production) buffaloes' meat had lower rigor onset values and less $\mathrm{pH}$ variation than young males (from meat production). However, the carcasses temperature decay suggests that the chilling system used was responsible for the rapid depletion of glycogen and reduction in the $\mathrm{pH}$ values of male and female buffalo's muscles, contributing to a highquality meat. The lower shear force and fragmentation index in the female's meat indicate their higher meat tenderness and postmortem proteolysis than male meat. This suggests that buffalo female's meat derived from dairy production had similar technological quality, or even better, than that of males from meat production. Therefore, the female meat, which had been previously classified as of inferior quality, can be sold in more demanding meat markets. However, studies associated with the shelf life and sensory perception of these products (especially in comparison with beef) are still needed.

\section{Acknowledgments}

The authors would like to thank the Minas Gerais State Research Support Foundation (FAPEMIG; CVZ APQ-0331517) and the National Council for Scientific and Technological Development (CNPq; MCT 430206/2016-0) for their financial support and the FAPEMIG for granting the scholarship (Master's degree) to the first author. They also like to thank Mr. Renato Sebastiani and the Frigorífico Cowpig for offering conditions for the research.

\section{References}

ABCB. The buffalo (in portuguese). São Paulo, SP, 2020. <http://www.nelore.org.br/Raca>.

Aroeira, C. N., Torres Filho, R. A., Fontes, P. R., Ramos, A. L., Castillo, C. J. C., Hopkins, D. L., \& Ramos, E. M. (2020). Comparison of different methods for determining the extent of myofibrillar fragmentation of chilled and frozen/thawed beef across postmortem aging periods. Meat science, 160,107955 . 10.1016/j.meatsci.2019.107955

Culler, R. D., Smith, G. C., \& Cross, H. R. (1978). Relationship of myofibril fragmentation index to certain chemical, physical and sensory characteristics of bovine longissimus muscle. Journal of food Science, 43(4), 1177-1180. 10.1111/j.1365-2621.1978.tb15263.x

Destefanis, G., Brugiapaglia, A., Barge, M. T., \& Dal Molin, E. (2008). Relationship between beef consumer tenderness perception and Warner-Bratzler shear force. Meat science, 78(3), 153-156. 10.1016/j.meatsci.2007.05.031

Dransfield, E. (1994). Optimisation of tenderisation, ageing and tenderness. Meat science, 36(1-2), 105-121. 10.1016/0309-1740(94)90037-X

Ekiz, B., Yilmaz, A., Yalcintan, H., Yakan, A., Yilmaz, I., \& Soysal, I. (2018). Carcass and meat quality of male and female water buffaloes finished under an intensive production system. Annals of Animal Science, 18(2), 557. 10.1515/aoas-2017-0036

Galeazzi, P. M., Mercadante, M. E. Z., Silva, J. A., De Albuquerque, L. G., de Camargo, G. M. F., \& Tonhati, H. (2010). Analysis of culling probability in dairy buffalo using survival models. Animal, 4(8), 1325-1329. 10.1017/S1751731110000406

Honikel, K. O., \& Fischer, C. (1977). A rapid method for the detection of PSE and DFD porcine muscles. Journal of Food Science, 42(6), 1633-1636. 10.1111/j.1365-2621.1977.tb08444.x

Hwang, I. H., Park, B. Y., Cho, S. H., \& Lee, J. M. (2004). Effects of muscle shortening and proteolysis on Warner-Bratzler shear force in beef longissimus and semitendinosus. Meat science, 68(3), 497-505. 10.1016/j.meatsci.2004.04.002

Immonen, K., \& Puolanne, E. (2000). Variation of residual glycogen-glucose concentration at ultimate pH values below 5.75. Meat Science, 55(3), 279-283. 10.1016/S0309-1740(99)00152-7 
Research, Society and Development, v. 10, n. 6, e42810615814, 2021

(CC BY 4.0) | ISSN 2525-3409 | DOI: http://dx.doi.org/10.33448/rsd-v10i6.15814

Kandeepan, G., Anjaneyulu, A. S. R., Kondaiah, N., Mendiratta, S. K., \& Lakshmanan, V. (2009). Effect of age and gender on the processing characteristics of buffalo meat. Meat Science, 83(1), 10-14. 10.1016/j.meatsci.2009.03.003

Li, Q., Wang, Y., Tan, L., Leng, J., Lu Q., Tian, S., \& Mao, H. (2018). Effects of age on slaughter performance and meat quality of Binlangjang male buffalo. Saudi journal of biological sciences, 25(2), 248-252. 10.1016/j.sjbs.2017.10.001

Luz, P. A. C. D., Jorge, A. M., Francisco, C. D. L., Mello, J. L. M. D., Santos, C. T., \& Andrighetto, C. (2017). Chemical-physical characteristics of buffalo (Bubalus bubalis) meat subjected to different aging times. Acta Scientiarum. Animal Sciences, 39(4), 419-428. 10.4025/actascianimsci.v39i4.36799

Mello, J. L. M., Rodrigues, A. B. B., Giampietro-Ganeco, A., Ferrari, F. B., Souza, R. A., Souza, P. A., \& Borba, H. (2018). Characteristics of carcasses and meat from feedlot-finished buffalo and Bos indicus (Nellore) bulls. Animal Production Science, 58(7), 1366-1374. 10.1071/AN16556

Miller, G. L. (1959). Use of dinitrosalicylic acid reagent for determination of reducing sugar. Analytical chemistry, 31(3), 426-428. 10.1021/ac60147a030

Neath, K. E., Del Barrio, A. N., Lapitan, R. M., Herrera, J. R. V., Cruz, L. C., Fujihara, T., \& Kanai, Y. (2007). Difference in tenderness and pH decline between water buffalo meat and beef during postmortem aging. Meat science, 75(3), 499-505. 10.1016/j.meatsci.2006.08.016

Pearce, K. L., Rosenvold, K., Andersen, H. J., \& Hopkins, D. L. (2011). Water distribution and mobility in meat during the conversion of muscle to meat and ageing and the impacts on fresh meat quality attributes-A review. Meat science, 89(2), 111-124. 10.1016/j.meatsci.2011.04.007

Raj, K. R., Rao, R. J., Rao, D. N., \& Mahendrakar, N. S. (2000). Influence of direct and delayed chilling of excised female buffalo muscles on their textural quality. Meat science, 56(1), 95-99. 10.1016/S0309-1740(00)00027-9

Ramos, E. M., \& Gomide, L. A. M. (2017). Meat quality assessment: fundamentals and methodologies. Viçosa, MG, Brazil: Editora UFV.

Savell, J. W., Mueller, S. L., \& Baird, B. E. (2005). The chilling of carcasses. Meat science, 70, 3, 449-459. 10.1016/j.meatsci.2004.06.027

Silva, D. R., Torres Filho, R. A., Cazedey, H. P., Fontes; P. R., Ramos; A. L., \& Ramos, E. M. (2015). Comparison of Warner-Bratzler shear force values between round and square cross-section cores from cooked beef and pork Longissimus muscle. Meat Science, 103, 1-6. 10.1016/j.meatsci.2014.12.009

Soares, G. J., Arêas, J., \& Batistuti, J. (1995). Effect of high voltage electrical stimulation on buffalo meat conditioning. Current Agricultural Science and Technology, 1, 61-68. 10.18539/CAST.V1I2.119

Spanghero, M., Gracco, L., Valusso, R., \& Piasentier, E. (2004). In vivo performance, slaughtering traits and meat quality of bovine (Italian Simmental) and buffalo (Italian Mediterranean) bulls. Livestock Production Science, 91(1-2), 129-141. 10.1016/j.livprodsci.2004.07.013

Toldrá, F. (2017). Lawrie's meat science. Woodhead Publishing. 